\title{
Urgensi dan Visibilitas Konsolidasi Kajian MNCs dan Kajian INGOs dalam Studi Hubungan Internasional Dewasa Ini
}

\author{
Mochamad Yunus, Joko Susanto \& M. Muttaqien \\ Universitas Airlangga
}

\begin{abstract}
Abstrak
Tulisan ini berusaha menjawab pertanyaan bagaimana studi tentang MNCs-INGOs terkonsolidasi dalam studi Hubungan Internasional (HI). Dengan menggunakan metode library research dengan analisis data kualitatif ditemukan bahwa pengembangan suatu kajian MNCs-INGOs yang terkonsolidasi dalam studi HI tidak hanya mungkin untuk diketengahkan tetapi lebih jauh juga sangat mendesak untuk dilakukan. Urgensi pengembangan studi ini didasarkan pada kenyataan bahwa baik MNCs maupun INGOs telah berkembang secara masif sebagai aktor privat di ranah transnasional. Probabilitas untuk menjadikan studi ini mandiri adalah sangat mungkin sejalan dengan berkembangnya diskursus tentang internasionalisme. Bahkan, seandainya kajian mendalam dan menyeluruh dilakukan dalam persoalan ini, akan semakin dipahami kajian ini tidak hanya pada level diskursus internasionalisme, namun juga sampai pada eksplorasi strategi dan tata kelola atas MNCs dan INGOs di level global.
\end{abstract}

Kata kunci-kata kunci: MNCs, INGOs, trans-nationalism, internationalism

This article tries to answer how the studies of MNCs-INGOs consolidated in the discipline of international relations. By using library research method and qualitative data analysis, it is found that the studies of MNCs-INGOs are possible and urgent to be developed in the international relations discipline. The importance of this study based on the fact that both MNCs and INGOs have developed as private transnational actors massively. The possibility to be independent study of IR is provided by the discource of internationalism. Moreover, if the comprehensive research is conducted it can be understood the transformation of not just only in the level of discource of the internationalism, but also on the exploration of the strategy and the governance of the MNCs-INGOs globally.

Keywords: MNCs, INGOs, trans-nationalism, internationalism 
Di antara pergeseran penting yang menandai perkembangan dunia dalam dua atau tiga dasawarsa terakhir adalah kemunculan masif International Non-Governmental Organizations (INGOs). Akira Iriye, misalnya, mengungkapkan bahwa jumlah INGOs dalam dua atau tiga dekade terakhir telah tumbuh pesat melampaui pertumbuhan organisasi internasional publik yang dibentuk negara. Meminjam data Union of International Associations, jumlah Organisasi Internasional yang dibentuk negara atau yang lebih dikenal dengan istilah Inter Governmental Organizations/IGOs meningkat dari 280 di tahun 1972 menjadi 1530 di tahun 1984; sementara INGOs tumbuh dari 2.795 menjadi 12.686 di tahun yang sama. Jika cabang-cabang lokal dari masingmasingnya diperhitungkan, jumlahnya berturut-turut menjadi 7.073 IGOs dan 79.786 INGOs di tahun 1984 (Iriye 2002, 128).

Di sisi lain, perkembangan serupa tapi muncul lebih awal ditunjukkan oleh pertumbuhan masif perusahaan multinasional atau Multinational Corporations (MNCs). Kendati bentuk klasik persebarannya dijumpai bahkan dalam zaman merkantilisme dan imperialisme Eropa, pertumbuhan kontemporer MNCs secara masif mulai terlihat terutama seiring merebaknya globalisasi produksi pasca Perang Dunia II. Sebagai akibatnya, jika sebelumnya didapati perekonomian dunia yang secara umum digerakkan negara, memasuki tahun 1970-an dan setelahnya, sejumlah perusahaan multinasional yang beroperasi lintas negara bermunculan dan bahkan dalam beberapa hal menunjukkan postur ekonomi yang bahkan sekilas melampaui postur negara. Data tahun 2000, menyebutkan bahwa Wallmart Stores, sebuah retail Amerika Serikat yang beroperasi di banyak negara membukukan nilai tambah sebesar 67,7 miliar dollar AS, sementara pada tahun yang sama GDP Bangladesh hanya membukukan pendapatan per kapita 47,1 milliar dollar AS. Karenanya, jika Wallmart mencatatkan diri sebagai kekuatan ekonomi dunia nomor 44, Bangladesh berada delapan tingkat di bawahnya.

Tentu saja, data itu saja tidak cukup menunjukkan merosotnya kekuatan negara. Dengan kemampuannya membuat dan mengubah aturan main, secara kualitatif, negara tetaplah kekuatan ekonomi utama. Hanya saja dengan terjinakkannya sebagian dalam aturan-aturan yang menjadikannya kurang leluasa, kekuatan negara dewasa ini lebih banyak potensial adanya. Namun, di luar kecenderungan itu, telaah terhadap dinamika internasionalisme dalam separuh abad terakhir, dengan mudah akan terlihat betapa secara internasional, pertumbuhan pesat INGOs maupun MNCs sesungguhnya tidak berdiri sendiri, melainkan saling berkelindan dalam suatu kecenderungan besar yang oleh sekelompok ahli digambarkan sebagai gelombang "munculnya otoritas privat dalam pemerintahan global dewasa ini” (Hall \& Biersteker 2002, 3-22).

Pertumbuhan INGOs maupun MNCs dengan demikian tidak pernah berdiri sendiri, tetapi bagian dari satu kecenderungan besar yang dalam banyak hal juga ditandai oleh kemunduran beberapa otoritas international publik. Meningkatnya arti penting standarisasi berbasis kebutuhan pasar yang berlaku baku dalam tatakelola banyak hal di tingkat internasional menggantikan kebijakan maupun resolusi IGOs hanyalah satu di antara banyak contoh. Tentang ini beberapa studi telah membahas secara menarik manifestasinya di tingkat praktik, seperti yang dikembangkan Susanne Soederberg dalam pembahasan lebih lanjut yang menggarisbawahi pergeseran dari UNCTC yang lebih pro-negara ke Global Compact yang lebih pro-pasar dalam kode etik perusahaan multinasional (Soederberg 2006, 53-95). 
Sampai di sini, sebagai sesama pemerhati pertumbuhan dan arti penting peran-peran keagenan otoritas privat internasional, kaitan antara kajian MNCs dan kajian INGOs sesungguhnya melampaui apa yang terkemukakan dewasa ini. Tetapi perkembangan terpisah kajian MNCs dan kajian INGOs dewasa ini menjadikan sedikit sekali ruang bagi pembahasan memadai atas dinamika otoritas international privat di mana MNCs dan INGOs merupakan dua agensi terpentingnya. Padahal secara teoritik, baik MNCs maupun INGOs, diturunkan dari induk pemikiran yang sama. Kajian Kjell Goldman tentang perkembangan internasionalisme secara jelas mengemukakan akar-akar penting kemunculan kembalinya dalam seratus tahun terakhir dijumpai melalui dua pintu utama: organisasi internasional dan perdagangan bebas (Goldmann 1994, 5-12). Jika INGOs merupakan turunan langsung dinamika organisasi internasional, MNCs merupakan turunan langsung dinamika pasar bebas.

Dengan demikian, konsolidasi kajian MNCs dan INGOs dalam suatu pendekatan yang integratif dan mandiri selain penting juga menemukan kontekstualitasnya dalam tradisi internasionalisme yang sentral dalam studi HI. Tulisan ini mengungkapkan bahwa pengembangan suatu kajian MNCs-INGOs yang terkonsolidasi dalam studi HI selain mendesak juga sangat mungkin dilakukan. Sementara urgensi bagi konsolidasi keduanya disediakan oleh kebutuhan baru transnasionalisasi sektor privat yang kian masif, visibilitasnya sebagai sebuah kajian yang mandiri secara prospektif disediakan oleh pertautannya yang erat dengan diskursus internasionalisme dalam studi HI. Akan tetapi, alih-alih berhenti sebatas kajian atas dinamika internasionalisme, kajian MNCs-INGOs yang terkonsolidasi lebih jauh menyediakan ruang bagi penyelidikan komprehensif atas transformasi dan permutasinya yang kiat privat. Oleh karena itu, tidak cukup berkembang sebatas studi dinamika internasionalisme baru dalam kaitan dua aktor internasional privatnya yang paling sentral yakni MNCs dan INGOs; kajian MNCs-INGOs yang terkonsolidasi diharapkan juga menyediakan dasar lebih lanjut bagi eksplorasi prinsip-prinsip dan strategi-strategi dasar tatakelolanya yang melintas batas.

Untuk sampai pada tujuan ini, tulisan ini dikembangkan dalam sistematika berikut ini. Pertama, eksplorasi atas perkembangan terpisah kajian MNCs dan INGOs dalam studi HI selama ini. Kedua, eksplorasi atas visibilitas kajian-kajian inter-nasionalisme berikut beberapa eksperimen teoritik terkaitnya dalam menyediakan dasar-dasar teoritik pokok bagi pengembangan kajian MNCs dan INGOsyang terkonsolidasi. Ketiga, eksplorasi atas peluang-peluang konsolidasi kajian MNCs dan INGOs yang disediakan oleh beberapa pergeseran global kontemporer dan masalah tatakelola lintas batas yang mengikuti. Keempat, kesimpulan umum terkait urgensi dan visibilitas konsolidasi kajian MNCs dan INGOs dalam suatu studi organisasi dan bisnis internasional yang integratif dan mandiri.

\section{Kajian MNCs dan INGOs dalam Studi HI}

Meski muncul sebagai dua perkembangan internasional yang menonjol pasca Perang Dunia II, kajian-kajian terhadap perusahaan multinasional maupun organisasi non pemerintah internasional tumbuh sebagai dua kajian yang bersimpangan. Sebagai sesama anak kandung studi hubungan internasional, keduanya pada dasarnya berbagi banyak hal. Tetapi atas nama tuntutan kekhususan dan sebagai konsekuensi dari arah 
perkembangan, kebersamaan mereka menjadi kian sulit dikenali. Dibanding bertemu dalam satunya pendekatan, keduanya lebih banyak bersimpang-siur dalam sepinya persinggungan.

Kajian perusahaan multinasional sesungguhnya tidak dapat dikatakan baru. Sejak hampir setengah abad lampau perhatian terhadap agensi internasional yang satu ini telah dapat dikenali dalam beberapa jejak menonjol. Meski keberadaannya telah dikenali sejak lima ratus tahun lalu, kajiannya secara khusus merujuk pada perkembangan lima puluh tahun terakhir, tepatnya ketika perhatian mulai dicurahkan terhadap fenomena maraknya penanaman modal asing non-portofolio pasca Perang Dunia II. Pertanyaan pun muncul, mengapa di tengah pilihan untuk tetap menjalankan aktivitas perdagangan beberapa perusahaan memilih untuk menempuh jalan investasi langsung? Tidakkan itu secara ekonomi politik beresiko?

Stephen Hymer (1960) memelopori upaya pemahaman terhadap kemunculan perusahaan internasional itu melalui suatu kerangka kontekstual baru. Melalui klasifikasinya atas investasi luar negeri langsung di satu sisi dan investasi portofolio luar negeri di sisi lain, fenomena kemunculan perusahaan multinasional ini mendapatkan pijakan kuat secara definisi. Atas klasifikasinya ini, perusahaan multinasional secara mudah dibedakan dari investasi-investasi luar negeri terkait yang beroperasi melalui pasar saham internasional dan tidak meninggalkan jejak produksi multinasional yang cukup kuat. Hingga kini kegunaan definisi perusahaan multinasional dalam klasifikasi konseptual Hymerian ini masih sering dijumpai.

Tetapi baru di tangan Raymond Vernon (1966) jawaban sistematis terhadap persoalan pertama di atas mendapatkan rumusan memadai secara teoritik. Melalui teori siklus produknya yang terkenal, Vernon memusatkan perhatian pada bentuk-bentuk investasi langsung luar negeri yang terintegrasi secara horisontal, yakni pembukaan pabrik-pabrik untuk memproduksi barang-barang sejenis di berbagai tempat di luar negeri. Menurutnya, setiap produk harus melewati setidaknya tiga fase pokok untuk menopang metamorfosis perusahaan dari yang berskala lokal ataupun nasional menjadi lintas nasional: fase perkenalan atau inovasi, fase pengembangan proses atau pematangan, dan fase standarisasi atau pendewasaan. Dalam tiap-tiap fase itu peran-peran evolusi teknologi, persebarannya secara lintas ekonomi dan pergeseran keunggulan komparatif berperan penting.

Menurut Gilpin $(1987,236)$ teori siklus produk ini selain menggarisbawahi arti penting perusahaan multinasional berikut pola-pola kompetisi oligopolistik terkaitnya juga mengungkap peran-peran persebaran teknologi dan integrasi perdagangan dan produksi luar negeri dalam strategi-strategi perusahaan pada umumnya. Terkait pertumbuhan kajian perusahaan multinasional, kontribusi ini tentu instrumental dalam menentukan ruang lingkup maupun arah perkembangan bidang kajian. Dalam kaitan ini pergeseran Kajian MNCs dari sebuah cabang studi HI dalam isu-isu ekonomi politik-internasional menjadi sebuah cabang baru studi manajemen dengan perhatian khusus pada masalah-masalah pengelolaan organisasional perusahaan lintas nasional.

Munculnya perhatian terhadap arti penting perusahaan multinasional mula-mula dipahami sebagai sebuah fenomena dagang yang dapat ditemukan jawabnya dalam teori-teori keunggulan komparatif ala David Ricardo yang klasik. Tetapi belakangan 
diketahui bahwa ia tidak semata fenomena dagang biasa melainkan melibatkan suatu konsentrasi oligopoli kapital yang luar biasa. Melalui Vernon, variabel penting dari konsentrasi ini mula-mula ditemukan dalam arti penting keunggulan teknologi selain juga peran-peran standarisasi dalam prosesnya. Tetapi di tangan kaum strukturalis yang lebih kritis, relasi-relasinya yang unik terkait negara asal maupun negara tujuan turut diungkap.

Dalam kaitan inilah pertumbuhan perhatian terhadap persoalan perusahaan multinasional secara signifikan berperan penting dalam melahirkan cabang studi ekonomi-politik internasional dalam studi HI. Akan tetapi, seiring bergesernya perhatian kajian MNCs yang kian tertarik pada persoalan organisasional ketimbang persoalan kontesktual maupun struktural, arti penting studi-studi ekonomipolitik internasional dalam mewadahi kajian-kajian MNCs mulai tersaingi oleh meningkatnya beberapa upaya untuk menjadikan persoalan manajerial dan oleh karenanya mengundang peran-peran antusias studi-studi manajemen pada umumnya dalam mewadahi dan memberi ruang bagi pertumbuhan kajian-kajian perusahaan multinasional berikutnya.

Gelombang kedua kajian perusahaan multinasional yang dikemukakan Gilpin mengkonfirmasi kecenderungan ini. Setelah untuk beberapa saat berada dalam pengaruh Raymond Vernon, kajian perusahaan multinasional dalam periode berikutnya mencatat pengaruh besar teori Paul Krugman (1979) dalam menggulirkan apa yang disebutnya sebagai 'multinasionalisme baru' (Gilpin 1987, 235). Berbeda dengan Vernon yang mengetengahkan 'teori investasi yang terintegrasi horisontal', Krugman mengetengahkan 'teori investasi yang terintegrasi vertikal'.

Jika yang pertama merujuk pada serangkaian pusat-pusat produksi multinasional yang tersebar di berbagai tempat tetapi bekerja untuk memproduksi barang serupa, yang kedua menunjuk kepada sejumlah rantai produksi multinasional yang tersebar dan sekaligus tersusun sedemikian rupa di mana satu perusahaan atau pusat produksi dibuat lebih untuk memenuhi kebutuhan-kebutuhan input bagi perusahaan atau pusat produksi yang lainnya. Sampai disini teori klasik perdagangan internasional tidak saja membutuhan pemahaman baru terkait supply-chain atau rantai distribusi yang melintasi pelbagai sistem nasional tetapi juga membutuhkan pemahaman bagaimana perusahaan secara organisasional mengatur dan mengelolanya.

Dalam pergeseran kajian yang kian mengarah pada perbincangan organisasional inilah lantas beberapa pendekatan yang kental dengan nuansa ekonomi politik sebagaimana dikembangkan Stephen Hymer (1960) atau pendekatan yang sarat analisis perdagangan internasional seperti yang diketengahkan Charles Kindleberger (1962) dengan cepat kehilangan pengaruhnya. Sebagai gantinya, pendekatan Michael E. Porter (1990) yang notabene merupakan pioneer penting dalam kajian-kajian manajemen stratejik lebih banyak mendominasi arah dan dinamika kajian-kajian perusahaan multinasional memasuki dasawarsa 1990-an dan setelahnya.

Mengembangkan sudut pandang stratejik baru atas pertumbuhan dan perkembangan perusahaan multinasional pada umumnya, Porter percaya bahwa perusahaan multinasional dewasa ini tengah memasuki era baru. Sebagai konsekuensi dari integrasi vertikalnya, ia kini makin terhubung dalam suatu 'rantai nilai' aktivitas 
yang merentang dari ekstraksi, produksi hingga marketing. Sebagai konsekuensinya sejumlah besar pilihan terbuka dan menuntut kejelian dalam mengembangkannya. Ketimbang muncul sebagai konsekuensi-konsekuensi tak terhindarkan dari struktur dan lingkungan di mana ia berada, menurut Porter, pertumbuhan perusahaan multinasional saat ini justru beroperasi dalam logika sebaliknya: yakni pilihan-pilihan stratejik yang menentukan struktur dan lingkungan yang melingkupinya. Tidak semata-mata menggarisbawahi arti penting struktur dan dinamika lingkungan, Porter justru mengarahkan lensa perhatian kajian-kajian perusahaan multinasional pada arti penting dinamika-dinamika stratejik manajerialnya.

Pada titik ini, bukan hanya mendekatkan kajian-kajian perusahaan multinasional dengan studi HI, pendekatan Porterian dalam beberapa hal lebih mendekatkannya dengan studi-studi manajemen umum. Kaitan erat kajian perusahaan multinasional dengan studi hubungan internasional selama ini jika tidak dijembatani oleh arti penting aspek-aspek struktural atau kontekstual, dalam beberapa hal akan disokong oleh peran-peran teori perdagangan internasional dalam menggarisbawahi arti penting aspek ekonomi-politiknya. Tetapi melalui Porter, arti penting dua hal itu tersubordinasi oleh dinamika stratejik organisasional yang dalam banyak hal berorientasi internal. Akibatnya, selain lebih banyak mendorong pertumbuhan studi-studi manajemen stratejik atau manajemen internasional pada umumnya, pendekatan Porterian ini pada saat yang sama juga menjauhkan kajian-kajian perusahaan multinasional dari kepompong asalnya.

Senada dengan perkembangan kajian perusahaan multinasional umumnya, perkembangan kajian ornop internasional juga mengalami kecenderungan serupa. Perhatian embrional terhadap arti penting ornop internasional dijumpai mulamula dalam kritik-kritik penstudi hubungan internasional terhadap kecenderungan pendekatan neorealisme yang dipandangnya terlampau state-centred dan kurang memperhitungkan arti penting kehadiran aktor-aktor internasional baru. Melalui karya-karya pendahuluan Keohane dan Nye (1971), pionir utama kalangan pluralis liberal, studi HI diserukan agar lebih menaruh perhatian lebih terhadap meningkatnya kesalingtergantungan, transnasionalisme dan kemunculan isu-isu berdimensi global. Mereka percaya bahwa kombinasi dari ketiganya telah mendorong kemunculan suatu 'aktor non-negara' dalam politik dunia.

Kemunculan beberapa riset empirik untuk menguji kebenaran asumsi ini, tidak semata menganulir tetapi justru mengkonfirmasi peningkatan arti penting aktor baru ini. Kjell Skjelsbaek (1971), misalnya, dalam essay berjudul "the Growth of International Non-governmental Organization in the Twentieth Century" yang ditulis pada periode yang sama, mengumpulkan sejumlah data yang menunjukkan pertumbuhan cepat ornop internasional ini sejak 1900 dan terutama sejak Perang Dunia II. Hasilnya adalah prosentase jumlah ornop internasional yang makin meningkat dari periode ke periode. Dari sejumlah 1012 organisasi di tahun 1954 menjadi 1899 di tahun 1968, dari tumbuh sebesar 6,2\% dalam kurun 1954-1968 menjadi tumbuh 6,2\% dalam periode 1962-1968.

Studi empirik lain yang dilakukan Richard Mansbach dan John A. Vasquez (1981) sepuluh tahun kemudian menghasilkan kesimpulan yang lebih drastis lagi. Setelah meriset aktivitas aktor-aktor politik global yang berbasis Jerman Barat dan Amerika 
Serikat dalam kurun 1949-1975, keduanya menyimpulkan bahwa sebuah peradigma alternatif yang berbasis arti penting aktor-aktor non-negara mendesak untuk segera diketengahkan mengingat arti penting mereka yang meningkat dalam politik global. Dari tiga puluh aktor yang muncul dalam perimeter risetnya, misalnya, sembilan di antaranya adalah aktor non-pemerintah sementara dua di antaranya adalah anggota konggres yang beroperasi secara individual dan partai politik yang bergerak sebagai kelompok subnasional.

Hingga dasawarsa 1980-an, perhatian terhadap arti penting ornop internasional memang meningkat dalam studi hubungan internasional. Akan tetapi, secara umum perhatian itu masih berkembang dalam kerangka perbincangan terhadap arti penting non-negara, bukan dalam satu kajian INGOs atau kajian ornop internasional yang mandiri. Yang terjadi kemudian, sebagaimana kritik Banks $(1985,17)$, sebuah revisi atas kecenderungan state-centred studi hubungan internasional ketimbang kelahiran sebuah kritisisme yang terintegrasi. Meski berbagi kesamaan terkait banyak hal, kaum pluralis liberal hingga periode ini secara umum tidak sampai menyepakati sebuah kerangka bagi sebuah perhatian yang integral dan mandiri (Maghoori 1982, 17).

Tetapi perkembangan pesat kajian terhadap peran-peran sosial organisasi nonpemerintah yang dikembangkan studi-studi pembangunan di akhir 1970an dan awal 1980an dan studi ilmu politik memasuki tahun 1990an memberikan dampakdampak yang cukup mendasar. Berbeda dengan lambatnya kemajuan perhatian studi hubungan internasional, studi-studi pembangunan dan studi ilmu politik sejak awal menunjukkan perhatian yang meningkat pada peran-peran keagenan khusus organisasi non-pemerintah dalam pertama-tama program-program pemberdayaan ekonomi negara berkembang hingga kemudian meliputi pula program-program reformasi kelembagaan menyusul gelombang naik demokratisasi negara-negara dunia berkembang memasuki periode 1990-an.

Seiring perpisahan developmentalisme dari Keynesianisme, memasuki dasawarsa 1970-an upaya-upaya internasional bagi modernisasi negara berkembang secara perlahan menunjukkan gelagat berpaling dari keniscayaan peran-peran sentral negara dan bersiap untuk menatap antusias peran-peran pihak ketiga dalam distribusi maupun eksekusi bantuan-bantuan luar negerinya. Di sisi lain, kebutuhan-kebutuhan bagi perluasan pengaruh yang penting dalam Perang Dingin membutuhkan peranperan keagenan yang 'netral' dan luwes untuk menghindarkannya dari tuduhan intervensi. Kombinasi dua faktor ini secara signifikan mengatrol pertumbuhan kajiankajian ornop internasional yang lebih pesat dalam studi-studi pembangunan pada umumnya.

Bergesernya kebijakan negara-negara Barat terkait bantuan luar negeri negara berkembang menyusul konsensus tidak resmi menteri-menteri keuangan mereka bersama lembaga-lembaga keuangan dunia di Washington paruh kedua dasawarsa 1980-an tidak saja kian menancapkan perhatian dan pengaruh studi pembangunan terhadap kajian-kajian ornop internasional tetapi juga menarik kembali perhatian dan pengaruh studi-studi ilmu politik dalam problematika persoalan dan sistematika pendekatannya. Melalui Konsensus Washington itu, kebijakan bantuan internasional selain mempertahankan arti penting peran-peran keagenan sektor ketiga sekaligus juga didorong mundur dari wilayah-wilayah pemenuhan kebutuhan pokok atau 
infrastruktur dasar yang bersifat fisik dan bergerak lebih masuk pada wilayah-wilayah reformasi kelembagaan yang politis dan regulatif.

Melalui peluang-peluang untuk lebih terlibat dalam reformasi kebijakan ini pengaruh studi ilmu politik terhadap perkembangan kajian ornop internasional menemukan celahnya. Tetapi peluang lebih besar bagi peningkatan pengaruh mereka lebih lanjut disediakan oleh pergeseran perhatian studi ilmu politik menyusul demokratisasi Eropa Timur dan di berbagai belahan lain dunia. Pelajaran tak terduga dari pengalaman Eropa Timur membangkitkan perhatian terhadap konsepsi civil society. Meski telah dikenal sejak lama, perhatian terhadap arti penting konsepsi civil society mengalami kemerosotan serius seiring menguatnya arti penting negara dan geopolitik. Menyusul ambruknya Uni Sovyet dan demokratisasi di berbagai belahan dunia, perhatian terhadap arti penting konsepsi civil society menemukan momentumnya.

Bagi perkembangan kajian INGOs atau ornop internasional dampak bagi pergeseran ini berlangsung serius. Selain membuat perhatian terhadap arti penting keberadaannya kian berkembang luas, pergeseran ini membawa pengaruh besar terhadap bagaimana keberadaannya dipahami. Tradisi studi hubungan internasional, dalam madzab umumnya, berangkat dari keyakinan bahwa ke-beradaan otoritas puncak yang ekivalen negara-bangsa secara internasional absen, sementara studi ilmu politik sebaliknya justru berangkat dari asumsi atas keberadaannya. Oleh karenanya, respon studi hubungan internasional terhadap kehadiran ornop internasional paling jauh adalah mengem-bangkan suatu pendekatan transnasional yang lebih kompleks secara komposisi keagenan.

Tetapi oleh pengaruh studi-studi ilmu politik, kajian INGOs yang tidak berhenti sebatas trans-nasionalisme melainkan secara ambisius mengembangkannya dalam suatu kajian 'masyarakat sipil global' secara intensif mengemuka memasuki dasawasa pertama milenium baru ini. Representasi paling bersemangat dari kecenderungan ini di antaranya dijumpai dalam proyek 'masyarakat sipil global' London School of Economy and Political Science/LSE di mana sejumlah nama kondang kajian INGOs berkumpul dan menjadi motor di balik eksperimen studi politik global. Termasuk dalam kelompok itu adalah David Held (1996) yang terkenal dengan Demokrasi Kosmopolitannya dan juga Mary Kaldor (2003) yang terkenal dengan konsep Masyarakat Sipil Globalnya.

Masalahnya, konsepsi civil society secara domestik diandaikan sebagai organisasi sosial antara yang bergerak di antara negara dan keluarga. Sementara kekosongan otoritas puncak yang ekivalen negara dalam sistem politik internasional tentu menyediakan halangan tersendiri bagi kehadiran sebuah 'masyarakat sipil global' sesungguhnya. Sebaliknya, sejak lama studi hubungan internasional dalam cara pandang paling umumnya, percaya pada absennya otoritas puncak yang ekivalen negara di tingkat internasional. Oleh karenanya, alih-alih mengasumsikannya sebagai organisasi intermediary yang beroperasi vertikal, studi hubungan internasional lebih jauh melihatnya sebagai organisasi intermediary horisontal yang beroperasi di antara celah-celah kedaulatan negara.

Dalam pemahaman seperti itu, kendati mengakui peningkatan arti pentingnya, kajian INGOs dalam studi hubungan internasional sejatinya berkembang dalam fondasi dasar konsepsi internasionalisme Grotian dan tidak dicantolkan dalam fondasi dasar 
universalisme Kantian yang cenderung mensubordinasi arti penting negara-bangsa. Itulah sebab di tangan studi hubungan internasional bentuk paling inovatif dari perhatian terhadap masalah ornop internasional ini dijumpai dalam pengembangan konsepsi organisasi transnasional, sementara dalam pengaruh studi ilmu politik konsepsi organisasi transnasional kian terdesak oleh arti penting konsepsi masyarakat sipil global. Beberapa orang mungkin melihat pergeseran ini sebagai transisi minoral, tetapi terkait fokus penelitian ini pergeseran seperti itu mengetengahkan konsekuensi fundamental.

Seperti pola perkembangan kajian MNCs, perkembangan kajian INGOs secara umum juga kian terkaburkan fitrahnya sebagai anak kandung internasionalisme. Selain mengaburkan kontekstualitasnya untuk tumbuh dalam naungan studi hubungan internasional, ketercerabutan ini juga mengaburkan kesalingterhubungan yang mungkin antara keduanya. Tidak hanya membukakan kemungkinan lebih bagi pengembangan suatu kajian yang saling menjembatani, kajian-kajian MNCs dan INGOs dalam perkembangannya justru berkembang saling memunggungi. Ibarat anak kembar yang tercerai-beraikan, sebagai sesama pemerhati peran-peran meningkat agensi privat internasional, kajian MNCs dan INGO secara ironis justru lebih banyak tumbuh sebagai entitas terpisah dan minim interaksi.

\section{Internasionalisme sebagai Titik-Temu Konsolidasi}

Berlawanan dengan kecenderungan perkembangan kajiannya yang terpisah, pertumbuhan pesat perusahaan multinasional maupun organisasi non-pemerintah internasional di paruh kedua abad XX pada dasarnya bertemu dalam akar kesejarahan yang sama, yaitu gelombang pasang internasionalisme dunia yang bergulir lebih dari separuh abad sebelumnya. Menariknya, tidak hanya muncul sebagai prekursor penting pertumbuhan pesat perusahaan multinasional maupun organisasi non-pemerintah internasional, internasionalisme abad XX dalam sejarahnya muncul dalam kaitan erat kolaborasi keduanya. Kjell Goldmann $(1994,5)$, pakar internasionalisme kontemporer terkemuka, dalam uraian pembuka salah satu karyanya yang otoritatif mengemukakan bahwa, "Two traditions form the roots of the twentieth-century internationalism: the long history of proposals for international organizations and classical liberalism with its belief in the benefits of free trade."

Merujuk pada nama yang paling bersemangat dalam pengupayaannya, gelombang pasang internasionalisme abad XX itu dikenali sebagai internasionalisme Wilsonian, bentuk internasionalisme yang secara antusias diupayakan Woodrow Wilson, Presiden Amerika Serikat ke-28, meski secara ironis sempat ditolak Amerika Serikat, negeri yang dipimpin Wilson. Beruntung setelah mengalami masa surut seiring dua kali perang dunia, internasionalisme Wilsonian kembali mengemuka dan bahkan terlembagakan dalam pelbagai pranata institusional internasional pasca Perang Dunia II. Pertumbuhan pesat perusahaan multinasional maupun organisasi non-pemerintah internasional di paruh kedua abad XX secara umum tidak dapat dipisahkan dari pertumbuhan internasionalisme Wilsonian ini.

Tetapi mengapa perkembangan itu harus bertemu dalam internasionalisme Wilsonian? Bukankah paham internasionalisme mengakar lebih jauh dari pikiran- 
pikiran yang berkembang awal abad XX itu? Apa yang istimewa dari internasionalisme Wilsonian itu? Pemahaman memadai terhadap internasionalisme wilsonian tidak dapat dilepaskan dari konteks di mana ia dimunculkan. Internasionalisme wilsonian dalam taraf tertentu adalah jawaban terhadap kegagalan Concert of Europe dalam upaya kolektifnya memoderasi kepentingan-kepentingan yang saling bertikai di Eropa seratus tahun sebelumnya. Alih-alih, menjadi pranata yang inklusif, dan secara berkelanjutan menjadi perantara upaya-upaya kerjasama konstruktif dan demokratis, Concert of Europe dalam perkembangannya justru berlangsung eksklusif, reaksioner dan lebih sering jatuh sebagai kepanjangan tangan negara-negara besar dalam upaya imperial dan fasisme.

Menolak eksklusivisme dan kencenderungan imperial Concert of Europe, internasionalisme Wilsonian pertama-tama menghendaki sebuah pranata multilateral inklusif yang keanggotaan tidak berhenti sebatas negara-negara besar melainkan secara menyeluruh melibatkan seluas mungkin negara. Untuk meminimalisir kemungkinan penyalahgunaannya sebagai alat dominasi imperial sebagaimana sebelumnya pernag terjadi, internasionalisme baru itu menegaskan komitmennya pada kedaulatan dan hak penentuan nasib sendiri setiap bangsa; mendorong kerjasama internasional yang lebih luas melampaui urusan politik dan keamanan pada umumnya; serta menaruh kepercayaan besar pada kaitan tak terpisah antara demokrasi dan perdamaian dunia.

Dalam posisi dasar seperti itu, kendati mengadopsi paham internasionalisme baru yang lebih liberal, yang secara tegas berbagi keyakinan serupa dengan paham-paham idealisme Kantian terkait tautan penting perdagangan, demokrasi dan perdamaian dunia; internasionalisme Wilsonian secara umum mempertahankan pokok-pokok pemikiran internasionalisme Grotian terkait arti penting kedaulatan dan hak penentuan nasib sendiri setiap bangsa. Berbeda dengan Immanuel Kant yang menggantungkan harapan pada kehadiran suatu pemerintahan dunia, Thomas Hobbes yang sinis pada kemungkinan kerjasama institusional konstruktif antar negara, atau Karl Marx yang percaya pada kegunaan suatu kediktatoran proletariat tingkat dunia, Hugo Grotius percaya bahwa kerjasama yang konstruktif di tingkat dunia sedapat mungkin perlu diletakkan dalam keniscayaan suatu pranata yang mengakui prinsip dasar kedaulatan negara.

Maka selain mewarisi cara pandang Grotian, internasionalisme Wilsonian lebih lanjut mempertahankan posisi dasar internasionalisme klasik yang unik terkait ketegangan cara pandang realisme Hobbesian vis-a-vis universalisme Kantian. Tidak saja menolak kaum realis yang percaya bahwa konflik dan ketegangan dunia adalah realitas tak terhindarkan dari absennya institusi global yang ekivalen negara, posisi dasar internasionalisme secara umum juga menolak keyakinan kaum universalis atas urgensi pemindahan total lokus otoritas dari negara-bangsa ke suatu institusi tingkat dunia. Tentang posisi tengah ini Kjell Goldman mengkonfirmasi bahwa, "Internationalism occupies the middle ground in assuming that security and maybe power are unavoidably important concern of government but that even anarchyrelated incompatibilities of interest can be reduced. Furthermore, it may be taken to differ from both 'realism' and 'universalism' in regarding escalation-related causation of war as a fundamental poblem."(Goldmann 1994, 23)

Terkait penjelasan perihal asal-usul perang, misalnya, posisi talaelogis intelektual umumnya mengenal dua penjelasan: yang satu menganggap perang adalah 
konsekuensi tak terhindarkan dari ketidakselarasan kepentingan, sementara yang lainnya percaya bahwa perang lebih merupakan konsekuensi dari eskalasi konflik. Jika yang pertama merupakan posisi dasar realisme hubungan internasional, yang kedua adalah posisi pokok universalisme hubungan internasional. Internasionalisme, alihalih memihak pada salah satunya, justru tertarik pada kemungkinan kombinasi kedua hal tersebut dalam menghasilkan peperangan secara bersama. Oleh karenanya, dalam konsepsi dasar terkait pengertian dan hakikat perang, pendekatan internasionalisme mengembangkan suatu teori 'sebab-sebab ganda peperangan' yang menaruh perhatian besar pada kemungkinan-kemungkinan ketidakselarasan kepentingan maupun eskalasi konflik dalam mengakibatkan suatu perang secara bersama ketimbang berkonsentrasi pada salah satunya (Goldmann 1994, 22).

Dalam kaitan itu, posisi dasar internasionalisme secara umum dapat dirumuskan dalam setidaknya empat asumsi dasar berikut. Pertama, bahwa sebagaimana posisi realis umumnya, kaum internasionalis mengakui bahwa realitas dunia internasional yang anarkis adalah sumber ketidakselarasan kepentingan yang dapat berujung perang. Kedua, bahwa kendati mengakui kemungkinan ketidakselarasan kepentingan dalam anarkisme internasional yang berkonsekuensi perang, kaum internasionalis percaya bahwa ketidakselarasan kepentingan dapat dikurangi tanpa harus menghilangkan kedaulatan negara-negara. Ketiga, bahwa dalam banyak hal perang justru terjadi karena kegagalan menghalangi eskalasi konflik yang mengeksploitasi ketidakselarasan kepentingan ketimbang ketidakselarasan itu sendiri. Keempat, bahwa dari sana upayaupaya pengembangan hukum, organisasi, pertukaran dan komunikasi internasional yang lebih kuat secara umum diyakini kontributif bagi penurunan luas lingkup ketidakselarasan kepentingan maupun kemungkinan eskalasi konflik itu sendiri (Goldmann 1994, 23).

Dalam arti penting pengembangan hukum, organisasi, pertukaran dan komunikasi dalam pendekatan internasionalisme itulah fondasi bagi konsolidasi kajian MNCs dan INGOs secara teoretik menemukan kontekstualitasnya kembali. Sebagai pendekatan yang masih mengakui peran penting negara, tradisi internasionalisme secara konseptual tidak dapat dikatakan immune dari pertanyaan relevansi, terlebih lagi manakala masalah transnasionalisme yang melibatkan aktor atau agensi non-negara seperti MNCs dan INGOs dikemukakan kembali. Akan tetapi, penelusuran ulang kaitan eratnya dalam upaya pengembangan yang merentang dari soal kelembagaan dan organisasional yang formal hingga soal pertukaran dan komunikasi internasional yang informal, dalam beberapa hal, menyediakan banyak peluang bagi klarifikasi atas masalah relevansi ini.

Bukan rahasia lagi, pendekatan internasionalisme secara umum terbagi dalam dua tradisi: internasionalisme koersif dan internasionalisme akomodatif. Internasionalisme koersif dibedakan dari yang akomodatif dalam cara bagaimana pelembagaan kepentingan dicapai. Jika proses pelembagaan kepentingan secara internasional dicapai melalui mekanisme hukum dan organisasional yang menjamin kepatuhan mengikat maka ia termasuk jenis internasionalisme koersif, sedangkan jika pelembagaan kepentingan internasional yang ada berusaha dicapai melalui mekanisme pertukaran sukarela dan komunikasi terbuka, maka ia merupakan jenis internasionalisme akomodatif. Meski bukan klasifikasi yang mutually exclusive, pertumbuhan INGOs adalah reaksi lanjut dari mekanisme hukum dan organisasional yang koersif, sementara perkembangan MNCs adalah konsekuensi lanjut dari 
mekanisme pertukaran dam komunikasi internasional yang akomodatif.

Sejarah panjang internasionalisme abad XX dalam beberapa hal adalah sejarah perjalanan internasionalisme dari bentuk-bentuk umumnya yang koersif ke akomodatif. Pertama-pertama ia mengambil bentuk pendekatan-pendekatan formal yang bersendikan norma kesepakatan dan organisasi kelembagaan, baru kemudian secara bertahap mengembangkan pendekatan-pendekatan informal yang bersendikan pertukaran dan komunikasi sukarela. Dalam bentuknya yang formal itu peran negara berlangsung sangat sentral sementara dalam bentuknya yang informal dan sukarela, peran-peran negara mulai disaingi oleh peran-peran organisasi non-pemerintah maupun perusahaan internasional. Pergeseran pola kerjasama kelembagaan dari model-model intergovernmental ke inter-non-governmental ke model business-tobusiness di beberapa dasawarsa terakhir merupakan petunjuk penting bagi pergeseran pendekatan ini.

Pertumbuhan INGOs maupun MNCs dengan demikian tidak pernah berdiri sendiri, tetapi bagian dari satu kecenderungan besar yang dalam banyak hal juga ditandai oleh kemunduran beberapa otoritas international publik secara relatif. Meningkatnya arti penting standarisasi berbasis kebutuhan pasar yang berlaku baku dalam tatakelola banyak hal di tingkat internasional menggantikan kebijakan maupun resolusi IGOs hanyalah satu di antara banyak contoh. Tentang ini beberapa studi telah membahas secara menarik manifestasinya di tingkat praktik, seperti yang dikembangkan Susanne Soederberg dalam pembahasan lebih lanjut yang menggarisbawahi pergeseran dari UNCTC yang lebih pro-negara ke Global Compact yang lebih pro-pasar dalam kode etik perusahaan multinasional dewasa ini (Soederberg 2006, 53-95).

\section{Pergeseran Global dan Masalah Tata Kelola Lintas Batas}

Pada akhirnya pembenaran-pembenaran bagi urgensi dan visibilitas konsolidasi kajian MNCs-INGOs dalam suatu kajian yang integratif dan mandiri disediakan oleh pergeseran-pergesaran global yang diusung globalisasi dalam mengatrol arti penting masalah tatakelola lintas batas dewasa ini. Tidak hanya menyediakan dunia yang lebih terbuka, globalisasi dalam perkembangannya juga sebuah perubahan sosial mendasar yang membawa serta masalah-masalah organisasional baru. Dalam kaitan itu, kemerosotan otoritas publik hanyalah salah satu contoh, sementara sisanya adalah meningkatnya arti penting tata kelola lintas batas.

Walaupuntidakmudahuntukmendapatkan definisiglobalisasiyangmerepresentasikan inti perdebatan konseptualnya dewasa ini, sebuah rumusan dari Anthony Giddens (1990) yang menghubungkan globalisasi dengan konsekuensi-konsekuensi tak terhindarkan dari perluasan modernitas nampaknya relevan untuk dikemukakan kembali. Sebagai nama lain dari intensifikasi hubungan-hubungan sosial mendunia di mana peristiwa yang berlangsung di suatu lokalitas dapat mempengaruhi lokalitas lain yang terpisahkan sedemikian rupa jauhnya, globalisasi merupakan tantangan langsung bagi organisasi sosial yang mendasarkan diri pada kemutlakan ruang dan waktu.

Negara atau negara-bangsa tidaklah steril dari pengaruh-pengaruh relativisme sosial 
globalisasi itu. Sebagai konsepsi modern organisasi sosial yang mendasarkan pada 'monopoli penggunaan alat-alat kekerasan dalam suatu wilayah' (Weber 1948, 7778), negara dan sistem sosial yang mendasarkan pada sentralitas peran negara secara umum juga dihadapkan pada dilema eksistensial yang tidak mudah. Sebagiannya muncul sebagai konsekuensi tantangan globalisasi atas hubungan-hubungan spesial negara dengan suatu wilayah atau dampak lebih lanjut dari tantangan globalisasi atas monopoli penggunaan alat kekerasannya, sementara sebagian lainnya muncul dalam bentuk yang lebih sistematik lagi: yakni kemerosotan otoritas publik dalam sistem sosial.

Sistem internasional sebagai sistem yang mendasarkan pada peran negara atau negara bangsa sebagai unsur penting pembentuknya tidak juga luput dari persoalan kemerosotan ini. Setelah untuk beberapa saat bekerja keras mengembangkan suatu pranata internasional yang mengemban fungsi-fungsi interlokutor kepublikan utama di aras lintas negara-bangsa, sistem internasional harus menghadapi kenyataan bahwa pranata-pranata keprivatan yang juga bergerak di aras yang sama dalam beberapa hal justru tumbuh lebih cepat melampaui dirinya. Sebagai konsekuensinya, keberadaan pranata-pranata publik internasional yang masih berupa embrio itu justru mengalami kemerosotan secara relatif. Merujuk pada tipologi Hall dan Biersteker (2002, 3-22), kemerosotan otoritas publik itu di level internasional berhubungan dengan pada naiknya arti penting tiga pranata keprivatan utama: otoritas pasar, otoritas moral dan otoritas ilegal.

Berbeda dengan otoritas publik internasional yang ditegakkan dalam sistem keterwakilan dan bersifat otonomi, otoritas privat secara konsisten bergerak dengan mengutamakan performa dan efisiensi. Pengaruh globalisasi yang mendorong integrasi vertikal di satu sisi dan fragmentasi horisontal di sisi lain, menghasilkan peluang bagi keberlangsungan pentingnya performa dan efisiensi yang secara komparatif lebih terfasilitasi ketimbang keberlangsungan pentingnya keterwakilan dan otonomi. Dalam struktur globalisasi yang mencairkan sekat-sekat kebekuan interaksi, kelangsungan pentingnya otonomi tentu tertantang oleh keuntungan yang mungkin diperoleh dari perdagangan terbuka, sementara dalam skema globalisasi yang memimpikan setiap orang adalah representasi bagi dirinya sendiri, yang tersisa tinggal bagaimana menjaga performa diri.

Secara ekonomi, emansipasi otoritas privat ini menemukan bahan bakar yang diperlukan dalam kaitan erat globalisasi dan paham neoliberalisme selama ini. Selain memberikan ruang yang lebih leluasa pada pranata-pranata yang mengedepankan arti penting individu dan kreativitas privat, neo-liberalisme globalisasi secara agresif bahkan mendesak mundur otoritas-otoritas publik dari wilayah-wilayah sosialnya yang klasik. Pada saat sama, kecenderungan integrasi vertikal dan ekspansi organisasi ekonomi yang berkembang masif dalam globalisasi membuka peluang bagi konsentrasi ekonomi luar biasa yang tidak saja menjadikannya sangat mampu mengelola operasioperasi bisnis lintas negara tetapi juga melampaui negara dalam performa-performa akumulasi kapitalnya.

Konsolidasi horisontal dan emansipasi vertikal seperti yang terjadi dalam ranah ekonomi dijumpai juga dalam ranah moral. Secara sosial, globalisasi tidak hadir tanpa nilai. Sebaliknya, globalisasi acapkali hadir dengan bagasi penuh nilai. Merujuk pada 
Giddens (2002), kehadiran globalisasi adalah kehadiran kosmopolitanisme dalam bentuknya yang lebih terintegrasi dengan karakter universal kapitalisme selama ini. Sebagai akibatnya, ketegangan dan kontestasi ulang di antara sistem-sistem nilai sosial seringkali tak terhindari. Dalam beberapa kesempatan, kompromi dan penyesuaian baru tercapai sementara dalam beberapa kesempatan yang lain ketegangan dan kontestasi itu acap harus berujung konflik nilai. Konsolidasi horisontal dan emansipasi vertikal dalam banyak hal merupakan pilihan tak terhindarkan dari kebutuhankebutuhan kontestasi ini.

Meningkatnya fundamentalisme dan bentuk emansipasi keagamaan era globalisasi merupakan contoh menonjol. Akan tetapi tidak tepat tentunya jika mendefinisikan naiknya otoritas moral ini sebatas revivalisme keagamaan saja. Meningkatnya arti penting organisasi non pemerintah yang bergerak lintas nasional adalah bagian dari emansipasi ini. Seiring dengan meningkatnya arti penting mereka, bentuk otoritas privat --mengutip Lipschutz dan Fogel (2002)-tumbuh melalui setidaknya tiga cara. Pertama, otoritasnya dalam agenda setting isu-isu internasional utama. Kedua, otoritasnya dalam kompetensi kebidangan mereka. Ketiga, otoritasnya sebagai kekuatan progresif-normatif dunia.

Selain mendorong emansipasi otoritas privat yang mengumpul di sekitar garis persinggungan pasar dan moral, globalisasi dalam bentuk kontraproduktif juga mengakselerasi perkembangan otoritas-otoritas ilegal. Di tengah kemudahan akses internasional yang meroket dalam globalisasi, absennya otoritas publik dengan kemampuan monopoli kekerasan di tingkat internasional, meninggalkan sebuah power-vacuum di beberapa tempat. Semakin lemah suatu negara dalam menegakkan otoritasnya, semakin besar pula power-vacuum yang ditimbulkannya. Dalam banyak kesempatan, wilayah perbatasan, daerah konflik dan wilayah lautan bebas adalah daerah subur bagi tumbuhnya otoritas illicit ini. Maraknya pembajakan di wilayah perairan Somalia atau masih banyaknya peradilan liar di Afganistan merupakan contoh nyata dari pertumbuhan otoritas privat ini. Tetapi, pertumbuhan otoritas illicit ini tidak selamanya merupakan monopoli negara lemah atau negara konflik. Riset Williams (2002) terhadap pertumbuhan jaringan dan organisasi kejahatan transnasional di Rusia, misalnya, menunjukkan bahwa pertumbuhan otoritas ini bukanlah monopoli negara kecil dan lemah.

Dari sana setidaknya dua hal bisa disimpulkan terkait tantangan dan peluang yang disediakan globalisasi dalam hubungannya dengan naiknya otoritas privat ini. Pertama, bahwa naiknya otoritas privat baik dalam bentuknya yang bersumberkan pasar, moral maupun klaim-klaim illegal selainkan menunjukkan dinamika internal yang khas, juga beroperasi dalam logika-logika transnasional yang saling terkait. Mengikuti identifikasi Hall dan Biersteker (2002, 3-22), misalnya, logika itu bisa dirunut dari kegagalan institusi-institusi Weberian modern dalam merespon tantangan-tantangan transnasional globalisasi, peluang-peluang otonomi kelompok dan konsolidasi vertikal yang disediakan globalisasi dan pada akhirnya adalah munculnya problematika illegal sebagai konsekuensi absennya legitimasi kepublikan dalam operasi otoritasotoritas privat ini. Pertumbuhan otoritas privat dari yang berbasis pasar ke moral dan berkonsekuensi lanjut pada tumbuhnya otoritas-otoritas illicit yang illegal sepenuhnya mengkonfirmasi logika transnasionalisme tersirat ini. 
Kedua, bahwa dalam kaitan kesimpulan pertama, selain membukakan peluang bagi penyelidikan integratif dan mandiri atas persoalannya, arti strategis bagi tantangantantangan yang dimunculkannya membutuhkan kerangka teoretik yang memadai bagi upaya pemahaman komprehensif atas kesejajaran maupun keunikan persoalan yang ditimbulkannya. Dengan kata lain, selain membukakan peluang bagi penyelidikan integratif atas logika-logika umum yang mendasari operasi INGOs maupun MNCs, globalisasi secara tidak langsung juga meningkatkan perhatian teoritik terhadap penelusuran hukum-hukum transnasionalitas ini. Terkait problematika persoalan masing-masingnya yang khas, ini memang bukan tugas yang mudah, belum lagi ditambah upaya sektoral pendekatannya yang berlangsung selama ini. Akan tetapi jika beberapa terobosan studi-studi stratejik atas globalisasi dipertimbangkan dalam kaitan ini, peluang-peluang bagi konsolidasi itu dapat dibukakan kembali.

Berbeda dengan tradisi studi ilmu politik yang fokus pada arti penting kebijakan dan juga studi ilmu ekonomi yang berpusat pada arti penting keputusan, studi-studi stratejik globalisasi meletakkan perhatian utamannya pada arti penting strategi. Berbeda dengan domain kebijakan yang seringkali terbatas pada ruang publik atau domain keputusan yang bersifat privat, domain strategi merentang dari soal publik maupun privat. Bicara strategi adalah bicara tentang suatu konsep yang relevan baik secara publik maupun privat. Meski pada mulanya muncul sebagai kosakata militer, istilah strategi saat ini telah juga dikenal luas sebagai kosakata ekonomi. Bahkan dalam tradisi studi manajemen stratejik, oleh sebab daya rentang dan keluwesan relevansi lintas sektoralnya, arti penting strategi bahkan hampir melampaui arti penting manajemen itu sendiri.

Untuk beberapa saat, studi tentang strategi memang berkembang sebatas unit-unit nasional atau perusahaan. Tetapi dewasa ini, seiring dengan makin kompleksnya tantangan globalisasi, studi-studi strategi yang secara umum fokus pada pengembangan prinsip-prinsip dan pemahaman atas per-soalan 'tata-kelola lintas batas' berkembang semakin maju. Mengutip Ghemawat, ironi besar globalisasi adalah bahwa sebagai sistem ia tumbuh tidak atas dasar persamaan tetapi perbedaan. Oleh karena absennya otoritas yang ekivalen negara di tingkat global, hubungan dan pertukaran dalam globalisasi harus diselenggarakan dalam modus 'lintas-batas nasional'. Dari sana perbedaan kultur, pemerintahan dan sejenisnya memainkan peranannya sendiri. Dari sana pemahaman umum terhadap logika-logika dasar yang menggerakkan tata-kelola lintas batas layak mendapatkan perhatian khusus yang memadai.

Dari sinilah kemudian istilah global strategy atau strategi global muncul dan memantapkan ciri pendekatannya yang unik dibandingkan strategi-strategi lainnya. Jika strategi nasional maupun strategi perusahaan berangkat dari pemahaman tentang kesamaan dan kesatuan unit, strategi global sebaliknya berangkat dari perbedaan dan disparitas unit-unit. Strategi nasional maupun strategi perusahaan mengasumsikan keberadaan suatu unit dengan kemampuan untuk membuat kebijakan maupun keputusan yang setidaknya mengikat secara internal, tetapi dalam konteks tumpang tindih dan absennya otoritas serupa di tingkat internasional, strategi global harus berfikir sebaliknya. Tetapi justru karena itu, melalui pendekatan tata-kelola lintas batas ini, strategi global selain relevan dengan problematika otoritas-otoritas privat internasional yang merentang dari MNCs sampai INGOs juga menempatkannya mereka dalam satu altar kajian yang sama. Selain membukakan peluang bagi konsolidasi 
kajian keduanya, kekhasan pendekatan tata-kelola lintas batas di atas dalam banyak hal juga menyediakan rasionalitas dan justifikasi kuat bagi kemandirian studinya.

\section{Simpulan}

Dengan demikian, tinjauan sekilas dan serba sederhana terhadap akar-akar dari keterpisahan kajian MNCs dan kajian INGOs dalam studi hubungan internasional secara umum telah mengemuka tiga hal utama. Pertama, bahwa keterpisahan kajian MNCs dan kajian INGOs dalam studi hubungan internasional bukan semata merupakan resiko ontologis hubungan internasional sebagai subyek kajian, namun justru muncul sebagai dampak kelambatannya dalam merespon dinamika perkembangan studi yang diketengahkan studi terkait. Dalam studi-studi MNCs, misalnya, gerak cepat kajian manajemen stratejik ataupun ekonomi internasional dalam menarik masuk kajian-kajian MNCs dalam tradisinya turut berperan dalam menggerogoti perhatian kajian MNCs terhadap aspek-aspek politik maupun aspek-aspek kontekstual yang melingkupinya. Sebaliknya, kajian MNCs menjadi semakin berkutat dalam dinamika persoalan organisasional yang internal dan semakin jauh dari tradisi hubungan internasional umumnya. Megikuti jejak kajian MNCs, pertumbuhan kajian INGOs dalam kaitan pengaruh studi-studi pembangunan dan ilmu politik yang masif pasca Perang Dingin - sebagaimana telah ditunjukkan di bagian depan - juga menunjukkan arah perkembangan serupa.

Kedua, bahwa alih-alih muncul sebagai konsekuensi dari pengembangannya dalam tradisi khas studi hubungan internasional pada umumnya, keterpisahan itu dalam banyak hal justru muncul sebagai konsekuensi dari absennya internasionalisme sebagai pondasi dasar pengembangannya. Sebagaimana telah ditunjukkan di bagian kedua pembahasan, bahwa perkembangan arti penting MNCs maupun INGOs dalam akar tunjangnya berkorelasi dengan peristiwa-peristiwa penting yang menandai pasang gelombang internasionalisme Wilsonian. Tidak hanya lahir dalam rahim sejarah yang berhubungan, arti penting MNCs dan INGOs semakin terfasilitasi oleh sejarah perkembangan internasionalisme setahun terakhir. Seiring dengan perjalanan internasionalisme Wilsonian yang bergerak ekspansif dari modelnya yang koersif ke akomodatif, arti penting MNCs dan INGOs pun tumbuh seiring kemunduran arti penting kerjasama intergovernmental negara-negara.

Ketiga, bahwa tidak berhenti sebatas mengendurkan arti penting negara dalam kerjasama internasional umumnya, globalisasi yang tumbuh masif pada kuartal terakhir abad XX lalu secara strategis turut mefasilitasi tumbuh dan meningkatnya arti penting otoritas-otoritas privat. Yang menarik, tidak hanya mengakselerasi emansipasi otoritas privat dalam segala basisnya, globalisasi pada saat yang sama juga menghubungkan dan meletakkan pertumbuhan otoritas-otoritas privat dalam suatu kemungkinan terbuka bagi pemahaman integral atasnya. Dalam upaya pemahaman atas kesamaan dan kekhasannya sebagai otoritas privat lintas negara itu pula, kajiankajian strategi global tumbuh dan menemukan lahan suburnya. Kontribusi-kontribusi kajian strategi global dalam identifikasi dan eksplorasi logika-logika tatakelola lintas batas yang melandasi operasi otoritas-otoritas privat itulah yang pada gilirannya menyediakan kerangka integratif yang diperlukan bagi konsolidasi kajian MNCs dan INGOs dalam studi hubungan internasional nantinya. Dari sana, upaya-upaya 
bagi reuni si kembar yang terceraikan sekian lama, selain urgens juga visible untuk diupayakan segera.

\section{Referensi}

\section{Buku dan Chapter dalam Buku}

Banks, M. 1985. 'The Inter-Paradigm Debate', in M. Light \&J. Groom(eds)International Relations: A Handbook of Current Theory, pp. 7-26. London: Pinter.

Ghemawat,Pankaj. 2007. Redefining Global Strategy: Crossing Border in a World Where Differences Still Matter. Boston: Harvard Business School Press.

Giddens, Anthony. 1990. "the Institutional Dimension of Modernity", dalam the Consequences of Modernity, Stanford: Stanford Univ. Press, pp. 55- 78

2002. "Globalisation", dalam Runaway World: How Globalisation is Reshaping Our Lives, London: Profile Books Ltd., pp. 6-19

Gilpin, Robert. 1987. The Political Economy of International Relations. Princeton: Princeton University Press.

.2001. Global Political Economy: Understanding the International Economic Order. Princeton: Princeton University Press.

Goldman, Kjell. 1994. Logic of Internationalism: Coercion and Accomodation, New York: Routledge.

Hall, R.B. dan T.J. Biersteker. 2002. "the Emergence of Private Authority in the International System”, in R.B. Hall dan T.J. Biersteker, ed., the Emergence of Private Authority in Global Governance, Cambridge: Cambridge University Press, pp. 3-22

Held, David. 1996. Models of Democracy, Camridge: Polity Press

Hymer, Stephen. 1960. The International Operations of National Firms: A Study of Foreign Direct Investment. Ph. D. Dissertation, Department of Economics. Massachussetts Institute of Technology, 1960. Diterbitkan kemudian oleh MIT Press, 1976. 
Urgensi dan Visibilitas Konsolidasi Kajian MNCs dan Kajian INGOs dalam Studi Hubungan Internasional Dewasa Ini

Iriye, Akira. 2002. Global Community: the Role of International Organization in the Making of the Contemporary World, Berkeley: University of California Press.

Kaldor, Mary. 2003. Global Civil Society: an Answer to War. Cambridge: Polity Press.

Keohane, R.O. dan J.S. Nye ed. 1971. Transnational Relations and World Politics. Cambridge: Harvard University Press.

Kindleberger, Charles P. 1962. Foreign Trade and the National Economy. New Haven: Yale University Press.

Mansbach, R.W. dan J.A. Vasquez. 1981. In Search of Theory: A New Paradigm for Global Politics. New York: Columbia University Press.

Maghoori, R. and B. Ramberg ed. 1982. Globalism Versus Realism: International Relations' Third Debate. Colorado: Westview Press.

Porter, Michael E. 1990. 'The Competitive Advantage of Nations'. Harvard Business Review. March-April.

William, Phill. 2002. 'Transnational Organized Crime and the State' dalam in R.B. Hall dan T.J. Biersteker, ed., the Emergence of Private Authority in Global Governance, Cambridge: Cambridge University Press, pp. 161-182

Weber, Max. 1948. 'Politics as a Vocation', dalam H.H. Gerth dan C. Wright Mills ed., From Max Weber: Essays in Sociology. London: Routledge \& Kegan Paul, pp. $77-78$

\section{Jurnal dan Jurnal Daring}

Krugman, Paul. 1979. 'A Model of Innovation, Technology Transfer, and the World Distribution Income'. Journal of Political Economy, 87: 253-266.

Lipschutz, Ronnie D. dan C. Fogel. 2002. 'Regulation for the rest of Us? Global Civil Society and the Privatization of Transnational Regulations'. dalam in R.B. Hall dan T.J. Biersteker, ed., the Emergence of Private Authority in Global Governance, Cambridge: Cambridge University Press, pp. 115-140

Skjelsbaek, K. 1971. 'The Growth of International Nongovernmental Organization in 
the twentieth Century'. International Organization, 25 (3).

Soederberg, Susanne. 2006. "Global Governance and Corporate Responsibility", in Global Governance in Question, London: Pluto Press, pp. 53-95

Vernon, Raymond. 1966. 'International Investment and International Trade in the Product Cycle', Quarterly Journal of Economics, 80: 190-207 
Urgensi dan Visibilitas Konsolidasi Kajian MNCs dan Kajian INGOs dalam Studi Hubungan Internasional Dewasa Ini 